\title{
HERMITE-HADAMARD TYPE INEQUALITIES FOR RIEMANN-LIOUVILLE FRACTIONAL INTEGRALS OF $(\alpha, m)$-CONVEX FUNCTIONS
}

\author{
De-Ping Shi, Bo-Yan Xi and Feng Qi
}

Abstract. In the paper, the authors establish some new Hermite-Hadamard type inequalities for Riemann-Liouville fractional integrals of functions whose derivatives in absolute value are of $(\alpha, m)$-convexity.

Mathematics subject classification (2010): Primary 26A33; Secondary 26D15, 41A55.

Keywords and phrases: Hermite-Hadamard type inequality, $(\alpha, m)$-convex function, Riemann-Liouville fractional integral.

\section{REFERENCES}

[1] R.-F. BAI, F. QI, AND B.-Y. XI, Hermite-Hadamard type inequalities for the $m$ - and $(\alpha, m)$-logarithmically convex functions, Filomat 27 (2013), no. 1, 1-7; Available online at http://dx.doi.org/10.2298/FIL1301001B.

[2] S.-P. BAI, S.-H. WANG, AND F. QI, Some Hermite-Hadamard type inequalities for $n$-time differentiable $(\alpha, m)$-convex functions, J. Inequal. Appl. 2012, 2012:267, 11 pages; Available online at http://dx.doi.org/10.1186/1029-242X-2012-267.

[3] M. K. BAKUla, M. E. ÖZdemiR, AND J. PeČARIĆ, Hadamard type inequalities for $m$-convex and $(\alpha, m)$-convex functions, J. Inequal. Pure Appl. Math. 9 (2008), no. 4, Art. 96, 12 pages; Available online at http://www. emis.de/journals/JIPAM/article1032.html.

[4] J.-H. Deng AND J.-R. WANG, Fractional Hermite-Hadamard inequalities for $(\alpha, m)$ logarithmically convex functions, J. Inequal. Appl. 2013, 2013:364, 11 pages; Available online at http://dx.doi.org/10.1186/1029-242X-2013-364.

[5] S. S. DRAGOMIR, On some new inequalities of Hermite-Hadamard type for $m$ convex functions, Tamkang J. Math. 33 (2002), no. 1, 45-55; Available online at http://dx.doi.org/ penalty-\@M10.5556/j.tkjm.33.2002.304.

[6] S. S. Dragomir And G. Toader, Some inequalities for $m$-convex functions, Studia Univ. BabeşBolyai Math. 38 (1993), no. 1, 21-28.

[7] R. Gorenflo And F. MAinardi, Fractional Calculus: Integral and Differential Equations of Fractional order, Fractals and Fractional Calculus in Continuum Mechanics (Udine, 1996), 223-276, CISM Courses and Lectures, 378, Springer, Vienna, 1997.

[8] W.-H. LI AND F. QI, Some Hermite-Hadamard type inequalities for functions whose nth derivatives are $(\alpha, m)$-convex, Filomat 27 (2013), no. 8, 1575-1582; Available online at http://dx.doi.org/10.2298/FIL1308575L.

[9] V. G. MineşAN, A generalization of the convexity, Seminar on Functional Equations, Approx. Convex, Cluj-Napoca, 1993. (Romania)

[10] M. E. Özdemir, M. Avci, And H. Kavurmaci, Hermite-Hadamard-type inequalities via $(\alpha, m)$-convexity, Comput. Math. Appl. 61 (2011), no. 9, 3614-2620; Available online at http://dx.doi.org/10.1016/j. camwa.2011.02.053.

[11] F. QI AND B.-Y. XI, Some integral inequalities of Simpson type for GA-Econvex functions, Georgian Math. J. 20 (2013), no. 4, 775-788; Available online at http://dx.doi.org/10.1515/gmj-2013-0043. 
[12] Y. ShUANG, Y. WANG, AND F. QI, Some inequalities of Hermite-Hadamard type for functions whose third derivatives are $(\alpha, m)$-convex, J. Comput. Anal. Appl. 17 (2014), no. 2, 272-279.

[13] G. Toader, Some generalizations of the convexity, Proc. Colloq. Approx. Optim., Univ. Cluj-Napoca, Cluj-Napoca, 1985, 329-338.

[14] J.-R. WAng, X.-Z. Li, M. FeČKAn, AND Y. Zhou, Hermite-Hadamard-type inequalities for Riemann-Liouville fractional integrals via two kinds of convexity, Appl. Anal. 92 (2013), no. 11, 22412253; Available online at http://dx.doi.org/10.1080/00036811.2012.727986.

[15] B.-Y. XI, R.-F. BAI, AND F. QI, Hermite-Hadamard type inequalities for the $m$ - and $(\alpha, m)$ geometrically convex functions, Aequationes Math. 84 (2012), no. 3, 261-269; Available online at http://dx.doi.org/10.1007/s00010-011-0114-x. 